\title{
Trichomes on Pigeonpea [Cajanus cajan (L.) Millsp.] and Two Wild Cajanus spp.
}

\author{
J. Romeis, T. G. Shanower,* and A. J. Peter
}

\begin{abstract}
Trichomes have been modified in a number of crops to develop insect-tolerant genotypes. Pigeonpea, Cajanus cajan (L.) Millsp., is often heavily damaged by insect pests, and trichomes provide a potential insect resistance mechanism. The following study was conducted to identify and characterize the distribution of trichomes on pigeonpea and two wild species, $C$. platycarpus (Bentham) van der Maesen and C. scarabaeoides (L.) Thours. Three glandular (Types A, B, and E) and two nonglandular (Types $C$ and $D$ ) trichome types were identified with light and electron microscopy. Types $A, B, C$, and D were found on leaves, pods, and calyxes of all three Cajanus spp., except for Type $A$, which was not found on pods and calyxes of most $C$. scarabaeoides accessions examined. Because of their small size and rarity, Type $E$ trichomes were not considered in this study. Pods of $\boldsymbol{C}$. scarabaeoides were the most densely pubescent, followed by pods of $C$. cajan and C. platycarpus. Trichome density on pods varied significantly among pigeonpea genotypes and different accessions of $C$. scarabaeoides. Differences across seasons and in greenhouse versus field-grown plants were also significant. Leaves of $C$. platycarpus possessed the fewest trichomes, while $C$. cajan and $C$. scarabaeoides had highly pubescent leaves. The resistance of $C$. scarabaeoides pods to Helicoverpa armigera (Hübner) larvae reported in an earlier study is due to the high density of nonglandular trichomes. This wild species may thus be an important source for developing insect resistant pigeonpea.
\end{abstract}

$\mathrm{P}$ IgEONPEA is an important grain legume of the semiarid tropics and is attacked by more than 200 insect species (Lateef and Reed, 1990). The most devastating pest is the pod borer Helicoverpa armigera, which causes worldwide yield losses of more than $\$ 300$ million annually (ICRISAT, 1992). More than 14000 pigeonpea germplasm accessions have been screened in an attempt to identify sources of insect resistance, but only low levels have been detected (Lateef, 1992; Sachan, 1992). As a result, the search for resistant sources has been extended to include noncultivated Cajanus spp. Several species were initially recognized as potential sources of resistance to major pod-damaging insect pests (ICRISAT, 1980; Lateef et al., 1981), but little research has been devoted to this topic recently.

Trichomes and trichome exudates on plant surfaces play an important role in the host selection process of insect herbivores (Bernays and Chapman, 1994). The type of trichomes and their orientation, density, and length have been correlated with reduced insect damage in several crops (Jeffree, 1986; David and Easwaramoor-

J. Romeis, Institute of Plant Sciences, Applied Entomology, ETH Zenstrum/NW, Clausiusstrasse 25, 8092 Zürich, Switzerland; T.G. Shanower, Northern Plains Agricultural Research Lab., USDA/ARS, 1500 N. Central Ave., Sidney MT 59270; A.J. Peter, Nagarjuna Agricultural Research and Development Institute, $28 \mathrm{P} \& \mathrm{~T}$ Colony, Secunderabad 500 009, Andhra Pradesh, India. Approved as Journal Article No. 1977 by the International Crops Research Institute for the Semi-Arid Tropics (ICRISAT). Received 27 March 1998. *Corresponding author (tshanowe@sidney.ars.usda.gov).

Published in Crop Sci. 39:564-569 (1999). thy, 1988; Peter et al., 1995). They could therefore provide a potential resistance mechanism against $H$. armigera and other pests of pigeonpea. Bisen and Sheldrake (1981) and Navasero and Ramaswamy (1991) studied trichomes on $C$. cajan but no information is available on the trichomes of noncultivated Cajanus spp. The following study was conducted to characterize and compare the trichomes on $C$. cajan and two noncultivated species, C. platycarpus and C. scarabaeoides.

\section{MATERIALS AND METHODS}

The plant material used for this study was collected from field- or greenhouse-grown plants at the research station of the International Crops Research Institute for the Semi-Arid Tropics (ICRISAT), located near Hyderabad, India.

\section{Trichome Description}

Trichomes on pods, leaves, and calyxes of three Cajanus spp. were described from field-grown plant material from one genotype of $C$. cajan (ICPL 87) and one accession each of C. scarabaeoides (ICPW 82) and C. platycarpus (ICPW 68) during the 1994 cropping season. In this and all subsequent observations, fully expanded leaves and full-grown, green pods were selected. The plant material was fixed and prepared for electron microscopy by the methodology described by Reddy et al. (1995). Electron micrographs of the samples were taken with a JEOL JSM 35 CF (Tokyo, Japan) scanning electron microscope.

The presence of trichomes on pods, leaves, and calyxes were determined by observing a minimum of 10 plants from each Cajanus spp. with a light microscope. The density of pod and leaf trichomes was determined with an ocular measuring grid. Trichome density was measured on 20 pods (three observations per pod) and 15 leaves (three observations per leaf) collected from different plants of each Cajanus spp. Trichome density on leaves was calculated for the interveinal area of upper and lower surfaces separately. The sampling unit for trichomes on pods (locule area) of pigeonpea, C. platycarpus, and leaves of all three species was an area of $1.21 \mathrm{~mm}^{2}$ (Type C) or $4.84 \mathrm{~mm}^{2}$ (Types A, B, D). The sampling unit for trichomes on pods of $C$. scarabaeoides was an area of $0.13 \mathrm{~mm}^{2}$ (Type C) or $3.24 \mathrm{~mm}^{2}$ (Types A, B, D) because of the high density of Type $\mathrm{C}$ trichomes and the smaller locule area on this species. The mean of the three observations per pod or leaf was the experimental unit in the data analysis.

Trichome length was measured by gently pressing sticky, transparent tape to the pod surface. Trichomes adhered to the sticky surface. The tape was then fixed to a glass slide and trichome length was measured under a microscope with an ocular micrometer. Trichomes were collected and measured on pods from at least 10 different plants per Cajanus spp. In total, 120 Type A, C and D, and 14 Type B trichomes were measured per species.

\section{Variation in Trichome Density}

Intraspecific variation in trichome density was investigated with pods from 12 pigeonpea genotypes (ICPL 87, ICPL 151, ICPL 269, ICPL 84052, ICPL 86012, ICPL 86015, ICPL 88034, 

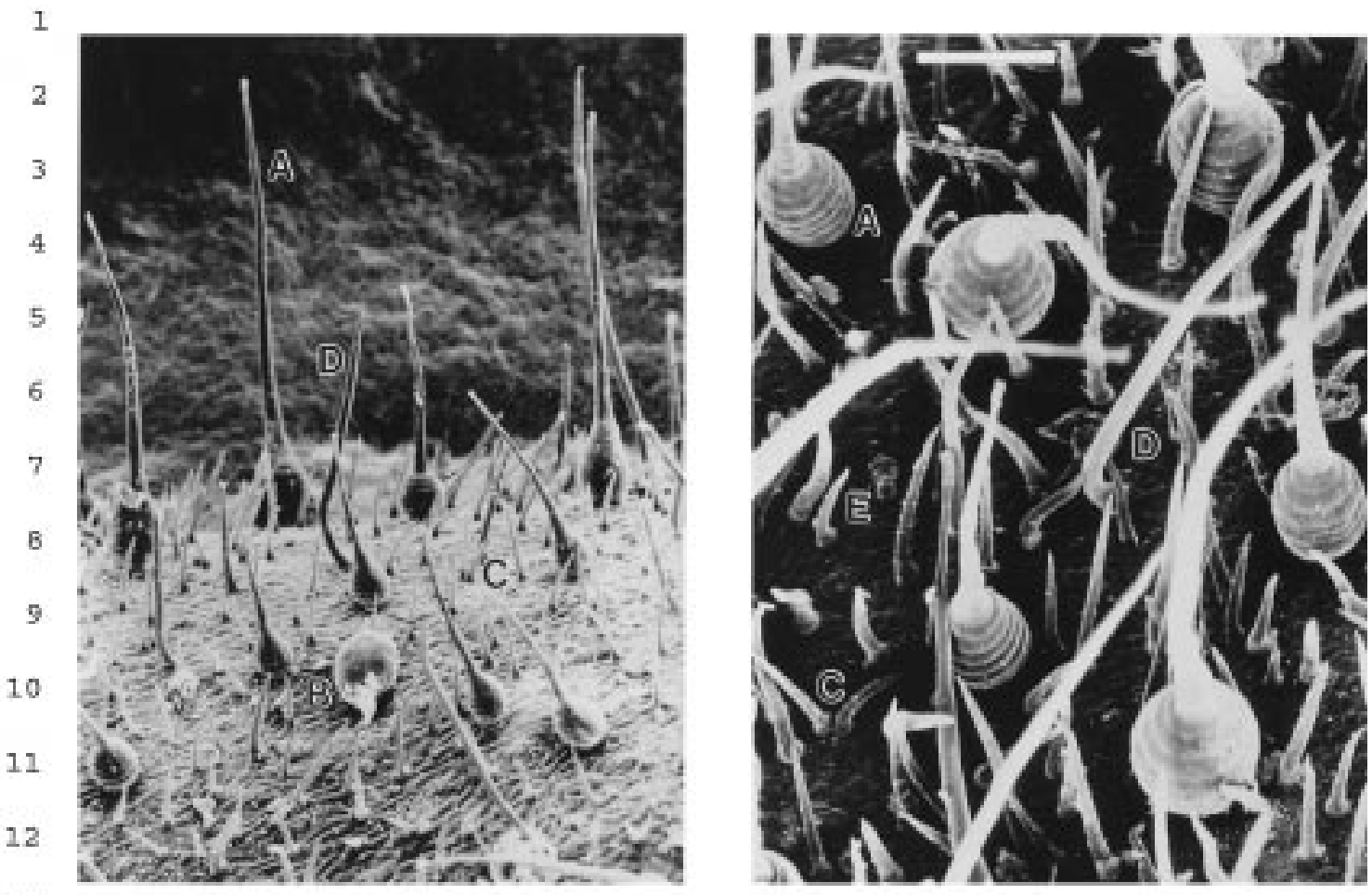

13

Fig. 1. Scanning electron micrographs of the pod surface of pigeonpea showing trichome Types A, B, C, D, and E. Scale on both plates equals $100 \mu \mathrm{m}$.

ICPL 89030, ICPL 90028, ICPL 95028, ICPL 95045, MPG 537) grown in the same field during the 1996 cropping season. For pigeonpea genotype ICPL 87, trichome density was compared on pods collected from field-grown plants during five seasons (four rainy and one post-rainy seasons between 1994 and 1997) and from greenhouse-grown plants during the 1995 and 1997 cropping seasons.

The trichome density on C. scarabaeoides was measured on pods of 11 accessions (ICPW 83, ICPW 94, ICPW 116 , ICPW 125, ICPW 130, ICPW 137, ICPW 141, ICPW 152, ICPW 278, ICPW 280, ICPW 281) grown in the field and greenhouse during the 1997 cropping season. Trichome density was compared among the different accessions and both environments and compared with two pigeonpea genotypes (ICPL 87, ICPL 86012) grown under the same conditions.

Trichome density for all pigeonpea genotypes and C. scarabaeoides accessions was observed on a minimum of 10 pods (three observations per pod) collected from 10 different plants with the ocular measuring grid described above.

\section{Statistical Analysis}

Analysis of variance (ANOVA) was used to compare the density and length of each trichome type among Cajanus spp., different pigeonpea genotypes, and C. scarabaeoides accessions with species, genotypes, and/or accessions as sources of variation (GENSTAT, 1995). The density of each trichome type was compared between greenhouse and field-collected pods of pigeonpea and C. scarabaeoides by an approximate $F$-test (GENSTAT, 1995). In these analyses, variation was partitioned among the following sources: environments (greenhouse, field), species (pigeonpea, C. scarabaeoides), accessions or cultivars within a species ( 11 for $C$. scarabaeoides, 2 for pigeonpea), interactions, and a pooled residual, which was used as the error term to calculate $F$ values. Means were compared by the least significant difference (LSD) at $P=0.05$.

\section{RESULTS}

\section{Trichome Description}

Five morphologically distinct types of trichomes (Types A-E) were identified from pods, leaves, and calyxes of the three Cajanus spp. by light and scanning electron microscopy (Fig. 1 and 2). Type A has a long tubular neck from which a clear viscous fluid is secreted. It is longer than all other trichomes except Type D (Table 1). The base is enlarged and appears to consist of 6 to 10 cells. The neck is comprised of 4 to 8 cells (Fig. 1 and 2). Type B is a yellowish, unsegmented globular sac. Its contents are only released after the cell wall

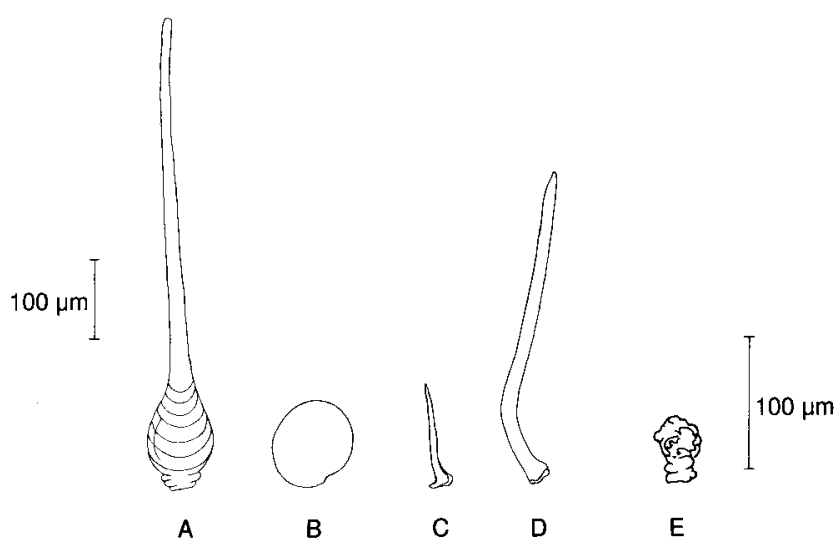

Fig. 2. Shape and size of five trichome types found on pods of pigeonpea. Scale on left for Types A through D; scale on right for Type E. Morphologically similar trichomes were found on C. scarabaeoides and $C$. platycarpus. For actual sizes see Table 1. 
Table 1. Mean length ( \pm SE) of four trichome types on pods of three Cajanus species grown in the field near Hyderabad, India (1994).

\begin{tabular}{|c|c|c|c|c|}
\hline Cajanus species & Type A & Type B & Type C & Type D \\
\hline C. cajan (ICPL 87) & $557 \pm 26 b \div$ & $86 \pm 3$ a & $116 \pm 4 b$ & $502 \pm 23 \mathrm{c}$ \\
\hline C. platycarpus (ICPW 68) & $780 \pm 25 a$ & $79 \pm 2 a$ & $263 \pm 10$ a & $2980 \pm 57$ a \\
\hline C. scarabaeoides (ICPW82) & $\mathbf{0}$ & $88 \pm 5$ a & $289 \pm 13$ a & $1315 \pm 42 b$ \\
\hline
\end{tabular}

$\dagger n=120$ (Types A, C, D), 14 (Type B).

$\leftarrow$ Means within a column followed by the same letter are not significantly different at $P=0.05$.

Table 2. Mean density ( \pm SE) of four trichome types on pods of three Cajanus species grown in the field near Hyderabad, India (1994).

\begin{tabular}{|c|c|c|c|c|}
\hline Cajanus species & Type A & Type B & Type C & Type D \\
\hline \multirow{4}{*}{$\begin{array}{l}\text { C. cajan (ICPL 87) } \\
\text { C. platycarpus (ICPW 68) } \\
\text { C. scarabaeoides (ICPW82) }\end{array}$} & & - numbe & $\mathbf{m}^{-2} \dagger$ & \\
\hline & $2.6 \pm 0.2 \mathrm{a} \uparrow$ & $0.09 \pm \mathbf{0 . 0 2} b$ & $71.4 \pm 4.7 b$ & $2.4 \pm 0.3 \mathrm{~b}$ \\
\hline & $2.5 \pm 0.2 \mathrm{a}$ & $0.12 \pm 0.02 b$ & $0.5 \pm 0.1 \mathrm{c}$ & $0.7 \pm 0.1 \mathrm{c}$ \\
\hline & $\mathbf{0}$ & $7.23 \pm 1.02 a$ & $155.6 \pm 3.9$ a & $5.4 \pm 0.6 \mathrm{a}$ \\
\hline
\end{tabular}

$\dagger \boldsymbol{n}=\mathbf{2 0}$.

$\downarrow$ Means within a column followed by the same letter are not significantly different at $\boldsymbol{P}=\mathbf{0 . 0 5}$.

is ruptured. Unsegmented nonglandular trichomes were separated into short (Type C) and long (Type D) trichomes. Type D is 4 to 11 times longer than Type C on all three species. In addition, electron micrographs showed a small, multi-lobed, glandular trichome (Type E), attached to the plant surface by a short stalk (Fig. 1 and 2). Type E trichomes are shorter $(<50 \mu \mathrm{m})$ than all other trichome types. Trichomes on $C$. platycarpus were longer than or equal to trichomes on $C$. scarabaeoides, and were significantly shorter on C. cajan than on either of the wild species (Table 1).

Trichome Types B, C, and D were found on pods and calyxes of all three species (Table 2). Type A trichomes were found on all $C$. cajan and $C$. platycarpus pods and calyxes observed. This trichome type was rarely observed on pods of three $C$. scarabaeoides accessions (see below), but was not found on calyxes of any accession. The density of each trichome type differed significantly among pods of the three Cajanus spp. (Table 2). Pods of $C$. scarabaeoides were more pubescent than pods from the other two species because of the higher densities of Types B, C, and D trichomes. Pods of C. cajan had more of the nonglandular Types $\mathrm{C}$ and $\mathrm{D}$, but similar densities of the glandular Types $\mathrm{A}$ and $\mathrm{B}$ trichomes, compared with C. platycarpus pods (Table 2).

In general, trichomes on leaves were much shorter than similar types on pods and calyxes. Trichome distribution on leaves was more complex and differed between upper and lower surfaces (Table 3), and on primary veins versus interveinal areas among the three species. Type A trichomes were found on the upper leaf surface and on leaf veins of the lower surface of all three species. Type A trichomes were also present on the interveinal area of the lower leaf surface of C. platycarpus, but these trichomes, if present, could not be seen on $C$. cajan and C. scarabaeoides because of the dense covering of Type $\mathrm{C}$ trichomes. Type $\mathrm{B}$ trichomes were found on both upper and lower surfaces of leaves of all three Cajanus spp. On leaves of C. cajan and $C$. scarabaeoides, Type D trichomes are present only on the primary veins and Type $\mathrm{C}$ is found in the area between major veins (see electron micrographs in Romeis et al., 1996). Both nonglandular trichomes are present on upper and lower leaf surfaces, including primary veins of $C$. platycarpus.

In contrast to the pods, leaves of $C$. cajan had significantly higher densities of trichomes, particularly Types $\mathrm{B}$ and $\mathrm{C}$, than leaves of the other two species (Table 3). The Type A trichome is more common on C. platycarpus than on the other two species. Except for Type A trichomes on $C$. platycarpus, large differences were observed in trichome density between the upper and lower surfaces for the same Cajanus spp. (Table 3). Leaves of C. scarabaeoides and C. cajan possess high densities of Type $\mathrm{C}$ trichomes on the lower surface and it was not possible to accurately determine their density.

\section{Variation in Trichome Density}

Trichome Types A through D were found on pods of all pigeonpea genotypes observed (Table 4). The density of Types A, C, and D trichomes varied signifi-

Table 3. Mean density of four trichome types on upper and lower interveinal surfaces of leaves from three Cajanus species grown in the field (1994).

\begin{tabular}{|c|c|c|c|c|c|c|c|c|}
\hline \multirow[b]{2}{*}{ Cajanus species } & \multicolumn{4}{|c|}{ Upper surface } & \multicolumn{4}{|c|}{ Lower surface } \\
\hline & Type A & Type B & Type C & Type D & Type A & Type B & Type C & Type D \\
\hline & & & numb & $( \pm$ SE) of $t$ & mes mn & & & \\
\hline C. cajan (ICPL 87) & $0.8 \pm 0.2 b \div$ & $3.43 \pm 0.48 \mathrm{a}$ & $373 \pm 24 a$ & 0 & $? \S$ & $10.01 \pm 0.73 \mathrm{a}$ & hpII & $\mathbf{0}$ \\
\hline C. platycarpus (ICPW 68) & $1.5 \pm 0.2 \mathrm{a}$ & $0.02 \pm 0.02 \mathrm{c}$ & $29 \pm 2 b$ & $0.7 \pm 0.1 \mathrm{a}$ & $1.6 \pm 0.2$ & $0.28 \pm 0.04 \mathrm{c}$ & $21 \pm 1$ & $0.1 \pm 0.02$ \\
\hline C. scarabaeoides (ICPW82) & $0.1 \pm 0.03 \mathrm{c}$ & $1.08 \pm 0.19 b$ & $51 \pm 6 b$ & $\mathbf{0}$ & $?$ & $3.05 \pm 0.35 b$ & hp & $\mathbf{0}$ \\
\hline
\end{tabular}

$\dagger \boldsymbol{n}=\mathbf{1 5}$.

Means within a column followed by the same letter are not significantly different at $\boldsymbol{P}=\mathbf{0 . 0 5}$.

$\S ?=$ presence uncertain.

II hp = highly pubescent $\left(>400 \mathrm{~mm}^{-2}\right)$. 
Table 4. Mean density ( \pm SE) of four trichome types on pods collected from 12 field-grown pigeonpea genotypes during the 1996 cropping season.

\begin{tabular}{|c|c|c|c|c|}
\hline Genotype & Type A & Type В & Type C & Type D \\
\hline & & 1 & & \\
\hline ICPL 87 & $2.8 \pm 0.3$ bcd $\$$ & $0.05 \pm 0.02$ abc & $25 \pm 2 c$ & $1.6 \pm 0.1$ ef \\
\hline ICPL 151 & $3.1 \pm 0.1 \mathrm{~b}$ & $0.06 \pm 0.02$ abc & $26 \pm 1 \mathrm{c}$ & $1.8 \pm 0.1 \mathrm{de}$ \\
\hline ICPL 269 & $2.4 \pm 0.1 \mathrm{~d}$ & $0.11 \pm 0.02 a$ & $32 \pm 1 \mathbf{a}$ & $2.2 \pm 0.1 \mathrm{bc}$ \\
\hline ICPL 84052 & $4.0 \pm 0.2 \mathrm{a}$ & $0.08 \pm 0.03$ abc & $30 \pm 1 \mathbf{a b}$ & $1.5 \pm 0.1 \mathrm{fg}$ \\
\hline ICPL 86012 & $2.4 \pm 0.2 \mathrm{~d}$ & $0.06 \pm 0.02$ abc & $25 \pm 1 \mathrm{c}$ & $1.9 \pm 0.1 \mathrm{~d}^{\circ}$ \\
\hline ICPL 86015 & $3.0 \pm 0.3 \mathrm{bc}$ & $0.08 \pm 0.02$ abc & $26 \pm 1 c$ & $1.4 \pm 0.1 \mathrm{fg}$ \\
\hline ICPL 88034 & $3.2 \pm 0.2 \mathrm{~b}$ & $0.04 \pm 0.02 \mathrm{c}$ & $27 \pm 1 \mathrm{bc}$ & $2.0 \pm 0.1 \mathrm{~cd}$ \\
\hline ICPL 89030 & $3.1 \pm 0.2 \mathrm{~b}$ & $0.07 \pm 0.02$ abc & $27 \pm 1$ bc & $2.2 \pm 0.1 \mathrm{bc}$ \\
\hline ICPL 90028 & $2.5 \pm 0.1 \mathrm{~cd}$ & $0.03 \pm 0.02 \mathrm{c}$ & $26 \pm 2 c$ & $1.3 \pm 0.03 \mathrm{~g}$ \\
\hline ICPL 95028 & $3.1 \pm 0.3 \mathrm{~b}$ & $0.07 \pm 0.02$ abc & $25 \pm 1 \mathrm{c}$ & $2.3 \pm 0.1 \mathrm{ab}$ \\
\hline ICPL 95045 & $2.4 \pm 0.2 \mathrm{~d}$ & $0.10 \pm 0.03 \mathrm{ab}$ & $27 \pm 1 \mathrm{bc}$ & $2.5 \pm 0.2 \mathrm{a}$ \\
\hline MPG 537 & $3.3 \pm 0.3 b$ & $0.05 \pm 0.02$ bc & $24 \pm 1 c$ & $1.5 \pm 0.1 \mathrm{fg}$ \\
\hline
\end{tabular}

$\dagger \boldsymbol{n}=\mathbf{1 0}$.

$\$$ Means within a column followed by the same letter are not significantly different at $P=0.05$.

cantly among genotypes. Similarly, significant variation was found for all four trichome types on pods of ICPL 87 collected during different seasons in the field and in the greenhouse (Table 5). When the two environments were compared, densities of Type A $(P<0.01)$, B $(P<$ $0.001)$, and $\mathrm{C}(P<0.001)$ trichomes were significantly higher on pods collected from greenhouse-grown plants compared to pods collected from field-grown plants. In contrast, the density of Type D trichomes was greater in field-grown plants than in greenhouse grown plants $(P<0.001)$.

Pods of $C$. scarabaeoides accessions grown during the 1997 cropping season were generally lacking Type A trichomes (Table 6). However, single Type A trichomes were found on one or two field-collected pods from three of the 11 accessions observed. For all other trichome types there was significant variation in density among the different accessions. As observed earlier (Table 2), C. scarabaeoides possessed significantly higher densities of trichome Types B, C, and D than pigeonpea (Table 6). Comparing the two environments, field-collected pods of $C$. scarabaeoides possessed significantly higher densities of Type A $(P<0.05), \mathrm{C}(P<0.001)$, and $\mathrm{D}(P<0.001)$ trichomes than pods collected in the greenhouse.

\section{DISCUSSION}

Cajanus spp. trichomes were the focus of this study because of their impact on insect pests and their natural enemies. Five types of trichomes were identified on pigeonpea and two wild Cajanus spp. The density of each trichome type differed significantly among pods and leaves of the three Cajanus spp. Trichome density also varied significantly among pods collected from different pigeonpea genotypes, C. scarabaeoides accessions, and among pods collected during different seasons or from different environments (field vs. greenhouse). It is well established that genotypic differences and environmental factors affect the growth and development of trichomes (Southwood, 1986). An important difference among the three species was the general lack of Type A trichomes on pods and calyxes of C. scarabaeoides, though single trichomes were found on pods of field grown plants of three accessions. This trichome type was also present on the upper leaf surface and leaf veins of $C$. scarabaeoides. Another important difference among the three Cajanus spp. was the substantially higher density of nonglandular trichomes on pods of $C$. scarabaeoides relative to the other two species.

Helicoverpa armigera, the key pest of pigeonpea, lays more than $80 \%$ of its eggs on pods and calyxes, as opposed to leaves (Romeis, 1997). The distribution and density of trichomes on these structures is therefore particularly important. Pods of $C$. scarabaeoides have the highest density of both types of nonglandular trichomes (Types C and D) among the three Cajanus spp. under both field and greenhouse conditions. Shanower et al. (1997) reported low survival (22\%) for neonate larvae on pods of $C$. scarabaeoides (ICPW 82) compared to pods of the other two Cajanus spp. (pigeonpea ICPL 87 , C. platycarpus ICPW 68 ), on which more than $72 \%$ of the larvae survived. The high density of nonglandular trichomes contributed to the high larval mortality on C. scarabaeoides as small larvae were unable to reach the pod surface and starved or desiccated before feeding. Long trichomes and the abundance of Type A exudates on reproductive structures also affect $H$. armigera natural enemies. The parasitization efficiency of Trichogramma spp. (Hymenoptera: Trichogrammatidae) egg parasitoids is significantly lower on pigeonpea pods and calyxes than on leaves (Romeis et al., 1998).

The function of the Type B trichomes is unknown. Bisen and Sheldrake (1981) suggested that this trichome is the source of the characteristic pigeonpea fragrance. The secretion in the Type B trichome is liberated only when the cell wall is ruptured. This could be caused by a chewing insect like $H$. armigera larvae or by abiotic factors such as high temperatures or low air humidity (Ascensão et al., 1995).

Bisen and Sheldrake (1981) considered Type E to be

Table 5. Mean density ( \pm SE) of four trichome types on pigeonpea (ICPL 87) pods collected from field and greenhouse grown plants.

\begin{tabular}{|c|c|c|c|c|c|}
\hline Environment & $n \dagger$ & Type A & Type B & Type C & Type D \\
\hline & & \multicolumn{4}{|c|}{ - number of trichomes $\mathrm{mm}^{-2}$} \\
\hline Field 1994 & 15 & $2.4 \pm 0.2 b \div$ & $0.07 \pm 0.01 \mathrm{c}$ & $62 \pm 2 b$ & $1.8 \pm 0.2 \mathrm{ab}$ \\
\hline Field 1995 & 20 & $2.9 \pm 0.2 \mathrm{~b}$ & $0.06 \pm 0.02 \mathrm{c}$ & $24 \pm 1 c$ & $1.9 \pm 0.1 \mathrm{ab}$ \\
\hline Field 1996 & 10 & $2.8 \pm 0.3 b$ & $0.05 \pm 0.02 \mathrm{c}$ & $25 \pm 2 c$ & $1.6 \pm 0.1 \mathrm{~b}$ \\
\hline Field 1996/97 & 10 & $2.7 \pm 0.1 b$ & $0.06 \pm 0.02 \mathrm{c}$ & $22 \pm 1 c$ & $1.0 \pm 0.1 \mathrm{c}$ \\
\hline Field 1997 & 10 & $2.8 \pm 0.3 \mathrm{~b}$ & $0.20 \pm 0.05$ ab & $64 \pm 3 b$ & $2.0 \pm 0.2 \mathrm{a}$ \\
\hline Greenhouse 1995 & 10 & $3.7 \pm 0.2 \mathrm{a}$ & $0.23 \pm 0.04$ a & $75 \pm 4 a$ & $1.1 \pm 0.1 \mathrm{c}$ \\
\hline Greenhouse 1997 & 10 & $3.0 \pm 0.1 b$ & $0.13 \pm 0.03$ bc & $77 \pm 2 a$ & $1.2 \pm 0.1 \mathrm{c}$ \\
\hline
\end{tabular}

$\dagger$ Number of pods observed.

$\$$ Means within a column followed by the same letter are not significantly different at $P=0.05$. 
Table 6. Mean density ( $\pm \mathrm{SE}$ ) of four trichome types on pods collected from field and greenhouse-grown plants from 11 . scarabaeoides accessions and two pigeonpea genotypes during the 1997 cropping season.

\begin{tabular}{|c|c|c|c|c|c|c|c|c|}
\hline \multirow{2}{*}{$\begin{array}{l}\text { Cajanus species/ } \\
\text { Genotype }{ }^{\dagger}\end{array}$} & \multicolumn{4}{|c|}{ Field collected } & \multicolumn{4}{|c|}{ Greenhouse collected } \\
\hline & Type A & Type B & Type C & Type D & Type A & Type B & Type C & Type D \\
\hline & & & & Imber of tri & mes & & & \\
\hline \multicolumn{9}{|l|}{ C. scarabaeoides } \\
\hline ICPW 83 & $0 \%$ & $11.08 \pm 0.61 \mathrm{a}$ & $140 \pm 7 \mathrm{f}$ & $9.6 \pm 0.3 \mathrm{a}$ & 0 & $6.97 \pm 0.37 c$ & $171 \pm 6 a b$ & $6.9 \pm 0.9 \mathrm{ab}$ \\
\hline ICPW 94 & $0.01 \pm 0.01 \mathrm{c}$ & $7.61 \pm 0.30 \mathrm{~cd}$ & $169 \pm 9$ bcd & $5.3 \pm 0.2$ ef & 0 & $6.73 \pm 0.90$ cd & $176 \pm 4 a$ & $5.2 \pm 0.3 \mathrm{def}$ \\
\hline ICPW 116 & 0 & $7.14 \pm \mathbf{0 . 5 2}$ d & $175 \pm 5$ bc & $5.4 \pm 0.2$ ef & 0 & $7.12 \pm 0.51 \mathrm{c}$ & $154 \pm 7 c$ & $5.2 \pm 0.4$ def \\
\hline ICPW 125 & $\mathbf{0}$ & $6.48 \pm 0.28 \mathrm{~d}$ & $178 \pm 8$ ab & $5.5 \pm 0.2 \mathrm{de}$ & 0 & $6.51 \pm 0.46 \mathrm{~cd}$ & $154 \pm 7 c$ & $4.9 \pm 0.3$ ef \\
\hline ICPW 130 & 0 & $8.42 \pm 0.61$ bed & $162 \pm 4$ bcde & $6.2 \pm 0.3 \mathrm{c}$ & 0 & $9.06 \pm 0.76 \mathrm{~b}$ & $132 \pm 6 \mathrm{e}$ & $6.6 \pm 0.3 \mathrm{bc}$ \\
\hline ICPW 137 & $0.02 \pm 0.01 c$ & $5.12 \pm 0.44 \mathrm{e}$ & $182 \pm 6$ a & $7.6 \pm 0.3 \mathrm{~b}$ & 0 & $\mathbf{5 . 5 4} \pm \mathbf{0 . 4 3} \mathbf{d}$ & $137 \pm 4$ e & $7.6 \pm 0.3 \mathrm{a}$ \\
\hline ICPW 141 & 0 & $4.46 \pm 0.23 \mathrm{e}$ & $184 \pm 9 a$ & $7.0 \pm \mathbf{0 . 4}$ b & 0 & $5.69 \pm 0.47 \mathrm{~cd}$ & $130 \pm 5$ e & $5.8 \pm 0.2 \mathrm{~cd}$ \\
\hline ICPW 152 & 0 & $\mathbf{6 . 6 8} \pm \mathbf{0 . 2 8} d$ & $193 \pm 7 \mathrm{a}$ & $7.9 \pm 0.4 \mathrm{~b}$ & 0 & $6.41 \pm 0.42 \mathrm{~cd}$ & $162 \pm 5 b$ & $6.4 \pm 0.2 \mathrm{bc}$ \\
\hline ICPW 278 & $0.02 \pm 0.01 \mathrm{c}$ & $7.44 \pm 0.26 \mathrm{~d}$ & $156 \pm 8$ def & $4.8 \pm 0.2 \mathrm{fg}$ & 0 & $9.09 \pm 0.62 \mathrm{~b}$ & $155 \pm 6 c$ & $4.6 \pm 0.3 \mathrm{f}$ \\
\hline ICPW 280 & o & $9.25 \pm 0.62 \mathrm{~b}$ & $159 \pm 5$ cde & $4.4 \pm 0.2 \mathrm{~g}$ & 0 & $10.57 \pm 0.29 a$ & $175 \pm 6$ ab & $5.4 \pm 0.2$ def \\
\hline ICPW 281 & 0 & $8.74 \pm 0.55$ bc & $1415 \pm 5$ ef & $6.1 \pm 0.3 \mathrm{~cd}$ & 0 & $8.64 \pm 0.72 b$ & $150 \pm 6$ cd & $5.5 \pm 0.3 \mathrm{de}$ \\
\hline \multicolumn{9}{|l|}{ C. cajan } \\
\hline ICPL 87 & $2.78 \pm 0.27 a$ & $0.20 \pm 0.05 f$ & $64 \pm 3 \mathrm{~g}$ & $2.0 \pm 0.2 \mathrm{~h}$ & $2.99 \pm 0.13 \mathrm{a}$ & $0.13 \pm 0.03 \mathrm{e}$ & $77 \pm 2$ f & $1.2 \pm 0.1 \mathrm{~g}$ \\
\hline ICPL 86012 & $\mathbf{1 . 3 7} \pm \mathbf{0 . 2 7} \mathrm{b}$ & $\mathbf{0 . 1 3} \pm \mathbf{0 . 0 4}$ f & $69 \pm 4 \mathrm{~g}$ & $1.5 \pm 0.1$ h & $2.43 \pm 0.14 b$ & $\mathbf{0 . 0 9} \pm \mathbf{0 . 0 2} \mathrm{e}$ & $72 \pm 4 \mathrm{f}$ & $1.8 \pm 0.1 \mathrm{~g}$ \\
\hline
\end{tabular}

$\dagger \boldsymbol{n}=\mathbf{1 0}$.

+ Means within a column followed by the same letter are not significantly different at $\boldsymbol{P}=\mathbf{0 . 0 5}$.

a developmental stage of Type B. Since no intermediate forms between Type $\mathrm{E}$ and Type $\mathrm{B}$ were found, we believe that Type $\mathrm{E}$ is a separate trichome type. A morphologically similar trichome has been described from cowpea, Vigna unguiculata Walpers (Oghiakhe et al., 1992). Because of the small size and relative rarity of Type E trichomes, they were not considered further in this study.

The distribution and size of trichomes on pigeonpea leaves were significantly different from those on pods and calyxes. Type A glandular trichomes were observed on pigeonpea leaves (upper surface) for the first time. They were not detected on the lower leaf surface but may have been hidden by the high density of Type C trichomes. Our results differ from those of Navasero and Ramaswamy (1991), who reported a two-fold higher density of glandular than nonglandular trichomes on C. cajan leaves. These authors also reported substantially lower densities of trichomes on $C$. cajan leaves than reported here (e.g., $1.4 \mathrm{~mm}^{-2}$ nonglandular trichomes on the upper surface versus $373 \mathrm{~mm}^{-2}$ in the present study). Genotypic and environmental differences are two possible explanations for this large variation in results. Navasero and Ramaswamy (1991) do not indicate which genotype of pigeonpea was used in their study.

Shanower et al. (1997) found trichomes on pods of Cajanus spp. to be an important resistance mechanism against $H$. armigera. These authors suggested that increasing the density of nonglandular trichomes on pigeonpea pods could reduce damage and losses due to pod-feeding insect pests. Results presented here show that C. scarabaeoides accessions possess substantially higher densities of nonglandular trichomes than pigeonpea genotypes and that these interspecific differences are apparent under both greenhouse and field environments. Work is currently in progress at ICRISAT to cross pigeonpea and $C$. scarabaeoides with the goal of developing pigeonpea genotypes with resistance to insect pests.

\section{ACKNOWLEDGMENTS}

We thank A.K. Murthy for producing the electron-micrographs, S. Chandra for statistical advice, and four anonymous reviewers for suggestions which improved the manuscript. Support to JR by 'Deutsche Gesellschaft für Technische Zusammenarbeit (GTZ)' is gratefully acknowledged.

\section{REFERENCES}

Ascensão, L., N. Marques, and M.S. Pais. 1995. Glandular trichomes on vegetative and reproductive organs of Leonotis leonurus (Lamiaceæ). Ann. Bot. (London) 75:619-626.

Bernays, E.A., and R.F. Chapman. 1994. Host-plant selection by phytophagous insects. Chapman \& Hall, New York.

Bisen, S.S., and A.R. Sheldrake. 1981. The anatomy of the pigeonpea Res. Bull. 5. International Crops Research Institute for the SemiArid Tropics (ICRISAT). Patancheru 502 324, Andhra Pradesh, India.

David. H., and S. Easwaramoorthy. 1988. Physical resistance mechanisms in insect plant interactions. p. 45-70. In T.N. Ananthakrishnan and A. Raman (ed.) Dynamics of insect-plant interactions: Recent advances and future trends. Oxford \& IBH Publ., New Delhi.

GENSTAT, 1995. Genstat 5, Release 2.2, Reference manual. Clarendon Press, Oxford, England.

ICRISAT. 1980. Pulse Entomology Progress Report 7. p. 45-47. International Crops Research Institute for the Semi-Arid Tropics. Patancheru 502 324, Andhra Pradesh.

ICRISAT. 1992. The medium term plan, Vol.1. International Crops Research Institute for the Semi-Arid Tropics. Patancheru 502 324, Andhra Pradesh.

Jeffree, C.E. 1986. The cuticle, epicuticular waxes and trichomes of plants, with reference to their structure, functions and evolution. p. 23-64. In B.E. Juniper and T.R.E. Southwood (ed.) Insects and the plant surface. Edward Arnold Publ. Ltd., London.

Lateef, S.S. 1992. Scope and limitations of host plant resistance in pulses for the control of Helicoverpa armigera. p. 31-37. In J.N. Sachan (ed.) Helicoverpa management: Current status and future strategies. Indian Institute of Pulses Research, Kanpur.

Lateef, S.S., and W. Reed. 1990. Insect pests of pigeonpea. p. 193-242. In S.R. Singh (ed.) Insect pests of tropical food legumes. John Wiley \& Sons, New York.

Lateef, S.S., L.J. Reddy, W. Reed, and D.G. Faris. 1981. Atylosia scarabaeoides: A source of resistance to Heliothis armigera. Intl Pigeonpea Newsl. 1:32-34.

Navasero, R.C., and S.B. Ramaswamy. 1991. Morphology of leaf surface trichomes and its influence on egg laying by Heliothis virescens. Crop Sci. 31:324-353. 
Oghiakhe, S., L.E.N. Jackai, W.A. Makanjuola, and C.J. Hodgson. 1992. Morphology, distribution and the role of trichomes in cowpea (Vigna unguiculata) resistance to the legume pod borer, Maruca testulalis (Lepidoptera: Pyralidae). Bull. Entomol. Res. 82:499-505.

Peter, A.J., T.G. Shanower, and J. Romeis. 1995. The role of plant trichomes in insect resistance: A selective review. Phytophaga (Madras) 7:41-64.

Reddy, M.V., V.K. Sheila, A.K. Murthy, and N. Padma. 1995. Mechanism of resistance to Aceria cajani in pigeonpea. Inter. J. Trop. Plant Dis. 13:51-57.

Romeis, J. 1997. Impact of plant characters and cropping systems on the searching behavior and parasitization efficiency of Trichogramma spp. egg parasitoids of Helicoverpa armigera. Ph.D. Thesis, University of Hohenheim, Germany.

Romeis, J., T.G. Shanower, and A.J. Peter. 1996. Type and distribution of trichomes on pigeonpea leaves. Intl. Chickpea Pigeonpea Newsl. 3:101-102.
Romeis, J., T.G. Shanower, and C.P.W. Zebitz. 1998. Physical and chemical plant characters inhibiting the searching behaviour of Trichogramma chilonis. Ent. Exp. Appl. 87: 275-284.

Sachan, J.N. 1992. Present status of Helicoverpa armigera in pulses and strategies for its management. p. 7-23. In J.N. Sachan (ed.) Helicoverpa management: Current status and future strategies. Indian Institute of Pulses Research, Kanpur.

Shanower, T.G., M. Yoshida, and A.J. Peter. 1997. Survival, growth, fecundity and behavior of Helicoverpa armigera (Lepidoptera: Noctuidae) on pigeonpea (Cajanus cajan (L.) Millsp.) and two wild Cajanus species. J. Econ. Entomol. 90:837-841.

Southwood R. 1986. Plant surfaces and insects - An overview. p. 1-22. In B.E. Juniper and T.R.E. Southwood (ed.) Insects and the plant surface. Edward Arnold Publishers Ltd., London.

\title{
Using a Subsample of the Core Collection to Identify New Sources of Resistance to White Mold in Common Bean
}

\author{
Phillip N. Miklas, ${ }^{*}$ Richard Delorme, Richard Hannan, and Michael H. Dickson
}

\begin{abstract}
Few sources of physiological resistance to the fungal pathogen Sclerotinia sclerotiorum (Lib.) de Bary, causal organism of white mold disease in common bean (Phaseolus vulgris $\mathrm{L}$.), have been found and exploited by breeders. Our objective was to screen a subsample of the core collection of $P$. vulgris accessions representing the active USDA National Plant Germplasm System collection of 1698 accessions from Central and South America for reaction to white mold using a greenhouse straw test. White mold reactions were rated for 89 accessions from $1=$ no disease symptoms to $9=$ total plant collapse. Eleven core accessions, PIs (plant introductions) 152311, 207136, 207154, 290990, 290995, 293353, 313850, 415886, 415906, 415913, and 415936, with scores $<5$ were identified as having putative physiological resistance to white mold. An expanded screening among 35 accessions from the active collection which had similar passport data to the resistant core PIs 207136, 290990, and 313850 revealed 20 resistant accessions with disease scores $<5$. A similar expanded screening of 18 accessions with similar passport data to core PIs 310674, 313608, and 415954 that had scores $>6$, revealed only four accessions with scores $<5$. These results indicated that a subsample of the core collection was useful for identifying ranges of accessions within the active Phaseolus collection that possessed a high incidence of putative physiological resistance to white mold.
\end{abstract}

$\mathrm{W}$ Hite MOLD, caused by Sclerotinia sclerotiorum (Lib.) de Bary, is one of the most important diseases of common bean worldwide. An integrated control strategy involving cultural practices (crop rotation, residue management, irrigation timing), fungicide applications, and resistant cultivars is necessary to combat this disease (Steadman, 1979). A combination of disease

P.N. Miklas and R. Delorme, USDA-ARS, 24106 N. Bunn Rd., Prosser, WA 99350; R. Hannan, USDA-Western Regional Plant Introduction Station, Johnson Hall, Washington State Univ., Pullman, WA 99164; and M.H. Dickson, Dep. of Horticultural Sciences, New York State Agric. Exp. Stn., Geneva, NY 14456. Received 27 March 1998. *Corresponding author (pmiklas@tricity.wsu.edu).

Published in Crop Sci. 39:569-573 (1999). avoidance, due primarily to upright architecture, and physiological defense mechanisms contribute to plant resistance (Dickson et al., 1982; Fuller et al., 1984; Schwartz et al., 1987; Miklas and Grafton, 1992). Factors that limit spread of the pathogen in plant tissue, such as increased activities of plant defense-related enzymes (Miklas et al., 1993) and phytoalexin accumulation (Sutton and Deverall, 1984), contribute to physiological resistance. However, the development of resistant cultivars has met with limited success because few sources of physiological resistance to white mold have been found and exploited in common bean breeding programs.

Core collections (Frankel and Brown, 1984; Brown, 1989), by providing a representative sample of the total accessions maintained in a germplasm repository, facilitate the evaluation of a wide array of genetic diversity for resistance to a complex disease like white mold. Once a core accession is identified with potential resistance to a disease, an expanded search for resistance can be conducted among accessions in the active collection with similar passport data. Longitude and latitude data from the collection site are lacking for most of the 13600 accessions in the Phaseolus collection maintained at the Western Regional Plant Introduction Station at Pullman, WA. Therefore, our expanded searches focused on a range of accessions, numbered consecutively and including the original core accession, which had a donor, collector, region, or marketplace in common. We investigated the use of this core collection approach for identifying novel sources of physiological resistance to white mold in the Phaseolus collection at Pullman.

\section{MATERIALS AND METHODS}

The Phaseolus collection, maintained at Pullman now totals over 13600 accessions, many of which were obtained from

Abbreviations: PI, plant introduction; SE, standard error. 